\title{
Crônicas da França equinocial: imaginários dos religiosos franceses na Amazônia oriental no século dezessete
}

José Guilherme dos Santos Fernandes

\section{Resumo}

Este artigo se propõe a tratar dos imaginários, e suas representações narrativas e imagéticas, transplantados na colonização da Amazônia brasileira no decorrer do século XVII utilizados pelos religiosos franceses e portugueses, em suas crônicas, a fim de traduzir para o Velho Mundo as paisagens e os costumes e aparências dos nativos americanos. Em particular, apresentaremos os relatos dos padres capuchos acerca do Maranhão, mediante a construção de um imaginário paradisíaco do território, mas que apresentava uma população selvagem que necessitava de um messias para conduzi-la à verdade e a Deus. Utilizaremos as obras de Claude d'Abbeville e Yves d'Évreux na exegese, pois estes foram religiosos que produziram crônicas mais significativas sobre a presença dos colonizadores na Amazônia Oriental no período. Para a análise dos textos utilizaremos referências da narratologia, da análise do discurso e dos estudos históricos.

Palavras-chave: imaginário; França Equinocial; Amazônia oriental; narrativas; interculturalidade 
Os processos de colonização no Mundus Novus não foram implementados tão somente pelas "armas e barões assinalados", ou seja, com a materialidade de homens e seus instrumentos de guerra. Talvez tão ou mais importante o foram os imaginários destacados para aqui "sentarem praça", nas mentes e corações dos nativos aborígenes. Exatamente deste aspecto que me proponho a tratar, especificamente na colonização da Amazônia brasileira a partir do século XVII, mais precisamente com a presença dos franceses, desde o ano de 1612, até a fixação da colonização portuguesa, em fins do mesmo século. Essa região da Amazônia brasileira teve destaque no processo de colonização, pois foi disputada por impérios vários da Europa, notadamente portugueses e franceses, além de espanhóis e holandeses. Desde fins do século XVI há notícias da presença francesa com o aventureiro Jacques Rifault, que em sua frota trazia Charles des Vaux, propagandista entusiasmado das riquezas do Maranhão. A partir das notícias deste, Daniel de la Touche adquire a concessão real para estabelecer uma colônia ao sul da Equinocial, em 1610, que efetivamente só se realiza em 1612. Da parte dos portugueses, que se estabelecem após a expulsão dos franceses em 1615, a região ganha notoriedade a tal ponto de ser uma colônia independente do Estado do Brasil durante aproximadamente 200 anos. Diz-nos Sampaio que

quando foi instituído como unidade administrativa diferente do Brasil em 1621, o Estado do Maranhão estava ligado diretamente a Lisboa. Instalado em 1626, foi temporariamente extinto em 1652 e logo reconstituído em 1654, com a denominação de Estado do Maranhão e Grão-Pará, sendo São Luís sua capital (...)

Na gestão pombalina, durante o reinado de D. José I (17501777), a separação se manteve ainda que a região tenha sofrido reordenamentos. Em 1751, extinguiu-se o Estado do Maranhão e Grão-Pará e, em seu lugar, foi instalado o Estado do Grão-Pará e Maranhão, sediado em Belém, compreendendo as capitanias do Grão-Pará, Maranhão, Piauí e - a partir de 1755 - a de São José do Rio Negro. Em 1772, uma outra intervenção criaria duas novas unidades na área: o Estado do Maranhão e Piauí e o Estado do Pará e Rio Negro. A sede deste último manteve-se em Belém e sua subordinação direta a Lisboa. Foi esse o quadro administrativo que persistiu até meados do século XIX. (SAMPAIO, 2003, p. 124).

Como podemos observar, até o século XIX havia não um Brasil, mas dois: um a partir do Ceará até o sul do país e outro do Maranhão, e Piaú como desmembramento deste, em direção a oeste do Brasil, ou seja, é como se a Amazônia fosse constituída por um grande Estado independente, com o Maranhão sendo sua porta de entrada.

Antes de tratarmos propriamente do fluxo dos imaginários transplantados pelo olhar estrangeiro dos franceses, e suas diásporas "civilizadoras", convém revisar o processo histórico e 
cronológico que retrata os contatos culturais, que favoreceram a tradução da cultura aborígene pelo imaginário e identidades do estrangeiro, mediante a escritura de crônicas, sermões e historiografia. Mesmo iniciado em 22 de abril de 1500, pelo primeiro contato entre europeus, diga-se portugueses, e ameríndios, a efetiva colonização, ou melhor, transculturação, no Brasil ocorreu em fins do século XVI, e na Amazônia brasileira esse contato, documentalmente, só se efetivou com a chegada dos colonizadores franceses em 26 de julho de 1612 à ilha de São Luís, no Maranhão (entenda-se que tratamos aqui da Amazônia legal, por isso considerarmos o Maranhão). Naquele momento, os franceses estavam capitaneados pelo almirante François de Rasily, juntamente com Daniel de la Touche, o senhor de la Ravardière. Nessa empreitada de fundação da França Equinocial, estavam presentes, como não podia deixar de ser, religiosos capuchos, destacando-se Claude d'Abbevile e Yves d'Évreux, além dos padres Arsène de Paris e Ambroise d'Amiens. Os dois primeiros, no entanto, nos legaram escritos importantíssimos para a compreensão não somente do nativo, mas do próprio colonizador e sua visão de mundo. Claude D'Abbeville (? - 1632) escreveu História da missão dos padres capuchinhos na ilha do Maranhão e terras circunvizinhas, publicado em 1614, dois anos após o retorno do religioso a Europa, e Yves d'Evreux (1577-1632), Continuação da história das coisas mais memoráveis acontecidas no Maranhão nos anos de 1613 e 1614, editado em 1615. Além disso, são os primeiros escritos que se têm notícia acerca da situação e condição da terra a ser colonizada, mesmo a despeito de apresentarem uma visão unilateral: essa limitação discursiva não pode ser justificativa para abandonarmos as crônicas desses colonizadores, pelo contrário, deve ser o motivo pelo qual podemos estudar as transculturações e interculturalidades geradas a partir desse momento, e mediante essas escrituras, a fim de entendermos a geração de práticas culturais entre fronteiras e deslocamentos, o que nos foi legado para a compreensão de nossa contemporaneidade. No prefácio do livro de d'Évreux, escreveu Ferdinand Denis, em reedição de 1864, sobre a importância da obra do religioso: "Yves d'Évreux não foi somente o pintor hábil, um narrador sincero, e sim também um observador perspicaz dos costumes de uma raça, para assim dizer extinta, e que não se poderia deixar de consultar" (ÉVREUX, 2007, p. LIII). Atemo-nos à expressão "raça, para assim dizer extinta" e concluiremos pela importância das escrituras desses religiosos. E essa conclusão já em meados do século XIX! Daí serem importantes escritos para entendermos nossa atual configuração étnico-cultural.

Além dos franceses, os portugueses também produziram escritos acerca da nova terra, no decorrer do século XVII, e figura importante, nesse sentido, foi nada menos que o Padre Antonio Vieira (1608-1697), festejado na literatura luso-brasileira, mas que de outro modo foi exímio político, no sentido de ser um planejador 
${ }^{1}$ A alusão ao Quinto
Império é uma determinação católico-cristã, baseada na profecia do rei babilônio Nabucodonosor (604-562 a.C.), em sonho que aparecia uma grande estátua com cabeça em ouro, peito e braços em prata, ventre e ancas em bronze, pernas de ferro e pés de barro. O profeta Daniel decifrou o sonho dizendo que a cada elemento que compunha a estátua correspondia um reino que dominaria a terra. Desde então, a cada momento histórico de dominação de um reino procura-se corresponder a um elemento da estátua, como as idades da civilização: Babilônia, Pérsia, Grécia e Roma; ou então Grécia, Roma, Cristandade e Colonização Euro-Americana. De qualquer modo, o Quinto elemento da estátua, como um provável Quinto Império, ainda é uma incógnita. do sentido de uma nação, construtor e vate de uma possibilidade de futuro para a terra brasilis com a projeção do Quinto Império ${ }^{1}$, anunciado em sua obra História do futuro publicada em 1718, mas baseada em tratado futurológico escrito por Vieira em Belém em 1659: Esperanças de Portugal, V Império do Mundo. Vale ressaltar que já no século XVII Padre Vieira destacava que o efetivo domínio e controle da costa brasileira significava a integração do Brasil, por terra, entre sul e norte, pois a navegação costeira era difícil em razão das fortes correntes e dos ventos contrários, que faziam com que fosse mais fácil ir-se de Belém ou São Luís para a Europa, o mesmo não ocorrendo entre estas cidades e a Bahia. A pacificação dos indígenas do litoral representava a real condição para que a empresa colonizadora do Brasil fosse efetivada, com a integração entre as regiões mediante locomoção rápida e fácil. Somente assim, para Vieira, o sonho do Quinto Império luso-católico poderia ser possível, pois haveria a possibilidade de se constituir uma nação mediante a evangelização dos indígenas. Para tanto, a região compreendida entre São Luís (MA) e Belém (PA), exatamente o nordeste do Pará, com a região bragantina, e o noroeste do Maranhão, com a baixada maranhense, seriam peças fundamentais na conquista do território e, com isso, territórios participantes do sonho do Quinto Império, desta feita como uma construção cristã no novo mundo. De qualquer maneira, o que fica registrado, e subentendido, é que, para Vieira, o Quinto Império estava no Brasil, mais especificamente na região em que atuou durante oito anos (1653-1661), na evangelização e construção de uma nação, seja pela instituição de uma nova "civilização" europeia entre os indígenas, seja pela materialização da conquista mediante a abertura de passagens que integrassem o país nascente a seu sonho missionário.

De fato, Vieira não chegou a plenificar seu sonho de um Quinto Império brasileiro, mas seu trabalho serviu para unificar a região entre Belém e São Luís, ainda no século XVII, ou seja, pelos feitos religiosos e político-militares de colonização e integração do Brasil pode-se construir, nesse espaço, uma região cultural, compreendida pela área de primeira colonização da Amazônia brasileira, a região oriental, compreendida entre São Luís (MA), a leste, e Belém (PA), a oeste, limitando-se ainda ao norte pelo oceano Atlântico e ao sul pelo bioma do cerrado brasileiro.

Por fim temos a obra de João Felipe Bettendorff (1625-1698), padre jesuíta que chegou ao Maranhão em 1661, juntamente com outros, por solicitação de Vieira, a fim de auxiliá-lo em seu sonho missionário na região. Bettendorff está mais para um historiógrafo da empresa jesuítica, mesmo que o título de sua obra principal sobre a Amazônia Oriental seja Crônicas da missão dos padres da Companhia de Jesus no estado do Maranhão, publicada em 1699, não sem razão o ano que fecha o século XVII, ou seja, o ciclo que nos propomos a tratar neste estudo. A obra de Bettendorff é 
interessante mais como levantamento complementar das questões apresentadas pelas teses de Vieira. Da mesma forma, a obra de d'Évreux será considerada como complementar a de d'Abbeville, o que já naquele momento era considerado pelo primeiro.

Estes quatro narradores, ou cronistas (assim compreendidos por terem, em princípio, o objetivo de narrar o cotidiano e hábitos do espaço em foco - por isso cronos, como registro do tempo e espaço-, sem necessariamente "intentarem" uma construção mais literária e/ou poética), com suas respectivas ficções, em perspectiva de complementação, constroem as narrativas fundadoras, no século XVII, não somente do território da Amazônia Oriental, mas de um imaginário ainda hoje recorrente na região amazônica: do paraíso perdido e terra de selvagens, que necessitam da vinda do messias para tornar pleno o sentido de terra da promissão. Aqui estudaremos os cronistas franceses já aludidos, e suas narrativas como construção histórica e mitologia política desse imaginário do ontem e do hoje.

\section{Imaginários transplantados}

O imaginário é conceito que está intimamente vinculado à construção e evocação de imagens pelo indivíduo, podendo ser, no campo da psicanálise, entendido pelo aspecto intrassubjetivo - da relação do sujeito com seu ego - ou inter-subjetivo - relação do sujeito com a imagem de seu semelhante. Isso implica dizer que, tal qual a memória, o imaginário tem uma relação com o individual e, ao mesmo tempo, com o coletivo, pois, enquanto um dos três registros do real lacaniano, o imaginário está intimamente vinculado ao sujeito, como formulador ou receptor de imagens a partir do "real". Existe, portanto, o imaginário individual e o coletivo, que são seccionados apenas em decorrência de melhor entendê-los, uma vez que a filiação do imaginário com o "real" implica em possibilidades que o situam, por um lado, em um determinado sistema simbólico, com fixidez das imagens representativas da realidade, mas, por outro, o afirma como capacidade produtora, pois o imaginário, como processo criador, "reconstrói ou transforma o real. Não se trata, contudo, da modificação da realidade, que consiste no fato físico em si mesmo (...), mas trata-se do real que constitui a representação, ou seja, a tradução mental dessa realidade exterior" (LAPLANTINE, TRINDADE, 1997, p. 27). Concluímos, assim, que o imaginário é uma construção de imagens baseadas na realidade física ou exterior, mas que é transformada quando da formulação de sua representação mental porque existe um processo de tradução, que entendemos sempre como cultural, que faz com que o real factual precipuamente não exista, em razão de que o imaginário é sempre uma representação, mediada pelos valores e visões de quem é detentor da competência, legalidade ou legitimidade para ser o tradutor: "o processo do imaginário constitui-se da relação entre sujeito e objeto que 
percorre o real, que aparece ao sujeito figurado em imagens, até a representação possível do real" (LAPLANTINE, TRINDADE, 1997, p. 27). Para nossos tradutores da Amazônia oriental no século XVII, explica-se que eram sujeitos individualizados - d'Abbeville e d'Évreux - e que seus textos são construídos a partir de suas percepções. Só que a percepção tangida pelo imaginário, como produção social, não é estritamente criação ou reflexo proposto pelo sujeito, ou um destes, porque atrás dele está a cultura como regramento do que pode ou não ser apreendido, ou pelo menos apresenta-nos o cardápio das imagens e percepções possíveis de existirem, pois as coisas e os seres, na esfera da cultura, só existem porque em algum momento foram nomeados e a eles foi atribuída uma imagem. Assim somos levados a entender que a cultura, em seu sentido simbólico, sobredetermina nossos reflexos, associando-os e estabelecendo esquemas (schémas) perceptivos mediante imagens convencionadas, organizadas em um conjunto dinâmico, o imaginário, que impõem representações mentais (ideias) de coisas "concretas" e "abstratas". Este é o sentido dos projetos colonizadores quando impõem cultus, que, oriundos, em princípio, do trabalho com a terra (a lavra, o trabalho cumulativo de gerações de lavradores) e da pretensa dominação das forças telúricas (celebrações memoriais, de reatualização das origens e dos ancestrais), constroem mitos e rituais de enquadramento e assimilação de nossas experiências perceptivas, como podemos "esquematizar" a partir de Durand: assimilação e acomodação sensório-motora + assimilação e acomodação mental = representação = imaginário.

Em razão do exposto, podemos afirmar que os autores em exegese foram tributários, em princípio, dos esquemas imagéticos coadunados em sua cultura de origem, mesmo porque suas percepções do real foram condicionadas pelo que deveriam ou não observar, segundo o habitus e a ideologia subjacente à empresa colonizadora. Mesmo sendo uma construção intangível, o imaginário se articula com os padrões da cultura "ab-origine" do tradutor, mas não quer dizer que este não tenha a capacidade criadora, para além dos esquemas perceptivos previamente determinados. Daí decorre que o tradutor cultural é o indivíduo que mais exercita a transculturação, porque, muitas vezes, representar uma cultura outra significa tentar enquadrá-la nas expectativas de sua própria cultura, só que existe o intangível que se refere ao fato de que nem sempre encontram-se correspondências entre elementos das duas ou mais culturas postas em contato. Em relação aos nossos autores, de modo geral, o grande desafio foi estabelecer as correspondências partindo-se dos parâmetros bíblicos e citadinos europeus, fazendo com que se produzisse uma narrativa intercultural, com a presença de interpretações em conformidade com que os tradutores "achavam o que era", tanto de sua cultura de origem quanto da cultura em contato. 
Essa particularidade fez com que os nossos narradores da Amazônia oriental fossem sujeitos que tiveram a responsabilidade de fundar o Mundus Novus amazônico, equilibrando as referências de sua história religiosa, militar e urbana com a percepção que tinham da "extasiante" natureza e do "exotismo" dos indígenas, procurando ancorar os seus sentidos com outras memórias do passado europeu, o que nem sempre era possível, e acabava gerando a transculturação, que

Implica en primer término una "parcial desculturación" que puede alcanzar diversos grados y afectar variadas zonas tanto de la cultura como del ejercicio literario, aunque acarreando siempre pérdida de componentes considerados obsoletos. En segundo término implica incorporaciones procedentes de la cultura externa y en tercero un esfuerzo de recomposición manejando los elementos supervivientes de la cultura originaria y los que vienen de fuera (RAMA, 2007, p. 45).

A partir de Rama, podemos concluir que o processo de transculturação se deslancha em três momentos: desculturação, aculturação e neoculturação. Acredito que este último vem ao encontro do conceito de interculturalidade, como objeto "final" e modelo gerado a partir dos contatos culturais, em sentido de tradução. Portanto, pensar a colonização, e suas narrativas e imaginários nascidos na fricção colonial, é compreender a produção relativa a uma terceira via de representação dos espaços e paisagens do Mundus Novus. E essa terceira margem pode ser visualizada na gênese da Amazônia oriental, para além das representações ipsis litteris do medieval.

Contrariamente ao que se afirma sobre a colonização no Brasil, não se desenhou unicamente o imaginário medieval na nova paisagem percorrida pelos europeus. E certo que muito do que se explicava estava baseado no medievalismo, como afirma Gimenez:

Foi, portanto, com base nas imagens produzidas dos relatos concretos ou imaginários dos viajantes e dos exploradores medievais que os europeus conceberam e figuraram suas impressões sobre o Brasil no período colonial, e uma das imagens perturbadoras que se fizeram presentes nesses viajantes diz respeito aos fabulários ligados aos monstros (2001, p. 210).

Não há de se negar que o enquadramento da percepção do espaço e da paisagem da América foi percebido mediante um padrão anterior, da cosmografia e geografia do medievo, mas também não podemos nos esquecer que as narrativas do Velho Mundo foram ressignificadas em nossas plagas, a exemplo do mito messiânico e daquele do Quinto Império: seja na descrição minuciosa da fauna e flora e dos indígenas, ou mesmo nos relatos dos feitos épicos dos colonizadores e da genealogia e embates dos nativos, o que subjaz é a "transfiguração poética" dos mitos europeus - o que já havia sido perceptível no batismo da região, 
nomeada Amazônia em referência às guerreiras da mitologia grega - e que "traduzem" a nova terra mediante o olhar e o repertório do estrangeiro. A narrativa de Dom Sebastião, o rei português desaparecido na batalha contra os mouros em Alcácer-Quibir, em 1580, se funde ao mito da terra da promissão, vindo desde a visão de Isaías, no Antigo Testamento, da chegada de um Príncipe da Paz.

Donde se conclui que os imaginários, destacados nas representações narrativas dos viajantes e cronistas aqui estudados, não apenas foram transplantados, mas adaptados à situação de colonização, afirmando a necessidade da empresa colonial mediante não mais as armas, mas pelos discursos impressos nos imaginários que afirmam a Verdade na voz do narrador. E a Verdade passa a ser um compósito de outras narrativas, que se centram na figura do Salvador, realizando em terra nova e nova paisagem os recalcamentos do mundo passado do desejante (narrador colonizador), ou do Desejado, ampliando o alcance das narrativas míticas agora ressignificadas coletivamente; lembra Girardet:

A partir do momento em que todo mito desse tipo ganha uma certa amplitude coletiva, ele tende a combinar vários sistemas de imagens ou de representações, a constituir-se, em outras palavras, como uma espécie de encruzilhada do imaginário onde vêm cruzar-se e embaralhar-se as aspirações e as exigências mais diversas, por vezes mais contraditórias (1987, p. 72-73).

Por isso não cabe tratar de uma transplantação nua e crua do imaginário europeu para o Brasil, pois houve a necessidade de atualização dos mitos para que fundassem, como cabe ao mito, novas realidades, não sem considerar o passado europeu. Pode haver o "mito primordial", mas todo o resto se constituiu como um mosaico a dar sentido ao arquétipo do Profeta, o anunciador de novos tempos. Nosso trabalho agora se deterá na identificação dos vários sistemas de imagens presentes (ou formações discursivas que remetem a formações ideológicas) a fim de descrever mais proximamente a "encruzilhada do imaginário" que se perfaz, apontando as ambiguidades, contrariedades e contradições.

\section{D'Abbeville e d'Évreux: crônicas de terra e gente}

Não sem propósito, a crônica de d'Abbeville trata, logo em princípio, da vinda de um salvador, de um messias, evidentemente os próprios franceses. Na chegada a ilha de São Luís, são convidados por Japiaçú, o principal, ou cacique, da nação Tupinambá, a maior etnia que habitava o litoral naquele momento, a visitarem a aldeia. O cacique fez longo discurso elogiando a vinda dos franceses, que estavam ali para salvá-los da fúria das outras nações inimigas e dos portugueses (os perós), além de iniciá-los na fé cristã mediante os padres (Paî):

Deus, porém, teve pena de nós e te mandou para cá (...) trazendo consigo muitos outros bravos soldados para defender-nos 
e Paí e profetas para nos instruir na lei de Deus. Alcançarás grande fama entre as altas personalidades por ter deixado um país tão belo como a França, tua mulher, teus filhos e todos os teus parentes, a fim de vires habitar esta terra, a qual embora não seja tão bela como a tua, e não tenha aqui todas as comodidades que poderias ter, te dará grande alegria, porque nela encontrarás caça em abundância e frutos, e o mar e os rios cheios de uma infinidade de peixes, e um povo valente que te obedecerá e te ajudará na conquista de todas as nações vizinhas" (2008, p.86-87).

É patente a alteridade no discurso de Japiaçú, posto que trata a França com certa "familiaridade", além de vaticinar exatamente o que os franceses gostariam de ouvir: seu papel de civilizadores do mundo, como os guerreiros de uma nova epopeia moderna, necessários para proteger os indefesos e alargar a fé cristã, dominando outras nações. Também em d'Évreux é recorrente o reconhecimento dos franceses como amigos e salvadores, a despeito do que relata o cronista em uma visita de um "maioral" dos índios ao forte dos franceses, em que este pronuncia: "os franceses sempre nos foram fiéis, vivendo em paz conosco, e acompanhando-nos à guerra, onde alguns morreram" (...) (d'ÉVREUX, 2007, p.37). Bem emblemático da figura do Salvador, do Messias. Essa alteridade nos impede de saber em que medida o relato do religioso se coloca como "fidedigno", pois existe a impossibilidade de "traçar uma linha de demarcação relativamente precisa entre a fabulação legendária e o relato de ordem histórica" (GIRARDET, 1987, p. 71). Isto porque a finalidade política da situação - justificar a presença dos franceses e a necessidade de conversão do gentio, com a consequente dominação e colonização da região - imiscui-se com narrativas europeias de caráter bíblico e/ou histórico, para lembrar o desígnio dos Profetas ou a vinda do Encoberto Dom Sebastião, por exemplo. Enquanto texto épico, a construção dos franceses é marcada pela contrariedade, ou seja, há necessidade de se afirmar o contrário para que se amplifique a necessidade do Salvador que irá tirar de campo o inimigo, o vilão que atormenta as vítimas.

O comparativismo é um recurso usual na crônica dos franceses, para equiparar a natureza do novo mundo ou as gentes que ali habitavam com o "modelo" europeu. Ao tratar da natureza, diz d'Abbeville: "embora tenhamos em França muitas qualidades de pássaros e de caça excelente ao paladar, não há comparação com o que se encontra no Brasil, já pela abundância e variedade das espécies, já pela sua beleza e utilidade" (2008, p.212). Também observamos recorrentemente a comparação entre os hábitos dos indígenas em relação aos dos franceses; tratando do casamento poligâmico, ressalta d'Abbeville:

E o que é mais admirável: vivem todas em boa paz, sem ciúmes nem brigas, obedientes todas ao marido, preocupadas com servi-lo dedicadamente nos trabalhos do lar, sem disputas nem dissenções de qualquer espécie. Espantou-me, e espanta- 
-me ainda quando dela me recordo, essa união observável nas famílias dos selvagens (...)

Bela lição em verdade para muitas famílias católicas, as quais, tendo recebido a luz da fé, devem viver santamente em seus lares, sujeitando-se a mulher, em tudo, a seu marido e senhor, temendo-o e respeitando-o como chefe (...). No entanto, apesar de tudo isso, não vivem essas famílias em paz, nem passam um só dia sem disputas e dissenções de toda espécie (...) (2008, p. 301).

Comparar vem a ser um recurso do tradutor cultural, como é o caso dos religiosos franceses. E mais, além de comparar para dar a dimensão da valoração ao receptor de seu texto, procura-se assumir uma postura política de supervalorização do objeto retratado, mediante descrições hiperbólicas da natureza, ou reflexões para lá de valorativas quando se trata das gentes, dos gentios, mesmo a despeito da adjetivação usual de "selvagens" aos nativos. Então, fica patente a polivalência dos nomes e qualidades impetradas no decorrer das crônicas, pois subliminarmente o que salta à percepção é a narrativa fundante de "terra rica de povo pobre", o que podemos anos depois observar em Euclides da Cunha ao tratar da Amazônia, no antológico livro À margem da história. Por isso a construção textual é um espaço de mediação, pois é categoria central da dialética, constituindo-se como elemento intermediário do conhecimento, conciliador entre teoria e prática; em uma palavra, a mediação é a práxis, quando lembramos a $2^{\mathrm{a}}$ tese de Feuerbach (MARX, ENGELS, 2007), que considera que só na práxis o homem demonstra a verdade e o caráter terreno de seu pensamento: a prática humana é o verdadeiro intermediário (mediação) entre a consciência e o objeto. Portanto, ideologia e imaginário, nesse momento, tornam-se sinônimos, e se realizam mediante o texto. É o que observamos no decorrer da produção dos cronistas franceses, além de observarmos como a ideologia pode facilmente ser posta em cheque pelo caráter contraditório dos textos.

A contradição se faz presente deveras. Exemplo é o fragmento da crônica em que d'Abbeville se refere à ausência de mercantilismo, o leit-motiv dos colonizadores, em relação aos indígenas:

Não sabem, pois, os índios, o que seja comprar e vender no intuito de juntar dinheiro, ouro ou prata, cujo valor desconhecem. Quando vendem seus escravos ou outros gêneros (...) fazem-no em troca de outras mercadorias (...). É por isso que vivem alegres e satisfeitos, sem pensar em trabalho. Quando não estão em guerra passam boa parte da vida no ócio, empregando o resto na dança, na cauinagem, na caça e na pesca, mais para alimentar-se e distrair-se do que para juntar riquezas (2008, p.319).

Belo exemplo da contradição no texto, pois, ao mesmo tempo em que elogia a vida "alegre e satisfeita" dos índios, o cronista 
francês não corrobora essa prática, uma vez que declaradamente a vê como ociosidade e ausência de trabalho, ou seja, a antológica "preguiça" indígena, despregada de qualquer ambição. A incompreensão pela prática cultural do Outro, a busca por uma outridade, o faz entender seu oposto com olhos de alteridade, vendo-o como um outro "ego" seu, um seu igual e que por isso deveria agir e pensar como ele: por certo, para ser como o colonizador, deve ser trazido às raias da "civilidade", daí a nascente visão antropológica evolucionista. A contradição nasce exatamente da incompreensão do diverso, uma vez que, por não terem parâmetros em relação a "ler" o Outro, os franceses consideraram unicamente a existência de um só parâmetro, e obliterados por essa névoa acreditaram ser portadores da Verdade. Assim o foi no decorrer de todo o processo colonizador nas Américas.

Yves d'Évreux é o continuador dessa visão - daí o título de sua obra ser Continuação - presente em d'Abbeville, com a diferença de que, por ter convivido mais tempo que este na região, durante dois anos com os indígenas, relata com mais propriedade os costumes e histórias destes, ao contrário de d'Abbeville, que se restringiu a conviver durante quatro meses (agosto a novembro de 1612). Por isso, a primeira parte de suas crônicas, o Primeiro Tratado, é dedicada a relatar, com mais acuidade, a vida do gentio. Causava estranheza ao religioso o tratamento dos indígenas em relação aos escravos capturados em guerra. Tão logo chegavam à aldeia do vencedor, os escravos eram incorporados a uma família na qual eram tratados como parentes, mesmo que tivessem que trazer os frutos de suas pescarias e caçadas ao seu senhor. Mas gozavam de certa liberdade em vista da prática europeia de tratamento dos aprisionados:

Desde então este infeliz cativo, por maior que seja entre os seus, se reconhece escravo e vencido, acompanha o vencedor, serve-o fielmente sem que seu senhor fique vigiando-o, tendo liberdade para andar por onde quiser, só fazendo o que for de sua vontade, e de ordinário casa-se com a filha ou a irmã de seu senhor, e assim vive até o dia em que deve ser morto e comido (d'EVREUX, 2007, p.46).

Desde logo encontramos contradição, pois, ao mesmo tempo em que afirma que o cativo é "infeliz", declara sua total liberdade no ir e vir, sem ser vigiado. Porque a conduta do cativo está baseada em código de honra, conduta que afirma que o escravo deve ser obediente ao seu senhor, e antes morrer em suas mãos do que fugir covardemente. Essa prática cultural, no entanto, não faz parte do ethos do europeu e assim torna-se incompreensível, aos olhos do religioso.

Outra contradição, entre os franceses, diz respeito ao trabalho. Enquanto d'Abbeville afirma a ociosidade do indígena, d'Évreux diz o contrário. Tratando da ajuda dos indígenas na construção do forte de São Luís, coloca: 
Apenas chegavam estes selvagens, entregavam-se ao trabalho com incomparável dedicação, mostrando na voz e nos gestos admirável coragem, parecendo antes que iam a um festejo de casamento do que para o trabalho, rindo e brincando uns com os outros, correndo a carregar a terra dos fossos para os taludes com uma emulação para ver quem empreendia mais viagens, e conduzia maior número de cestos de terra (2007, p. 20).

Aqui fica patente a compreensão diferenciada, culturalmente, do que seja o trabalho: para o colonizador, deveria ser separado da celebração, sendo atividade de dor e desprazer, pois a alegria estaria presente unicamente na festa. Para os indígenas festa e trabalho eram inseparáveis, sendo o labor oportunidade de sociabilidade e confraternização: pelo menos é o que se demonstra na descrição feita pelo religioso. E parece-me que esta prática relacionada ao trabalho ainda é recorrente entre populações tradicionais na região da Amazônia oriental, pois tive oportunidade de estudar uma manifestação da cultura popular em cidade costeira do Pará (São Caetano de Odivelas), em que a origem da brincadeira do boi-bumbá, ou boi de máscaras, estava ligada ao trabalho dos pescadores (vide FERNANDES, 2007).

Outra contradição observada em d'Évreux é relativa à timidez e medo dos indígenas: "Embora sejam por natureza tímidos e medrosos, nos combates ganham calor, não abandonam o campo de guerra, e quando perdem as armas pelejam com unhas e dentes contra os inimigos" (2007, p. 24). Como entender o sentido de medo e timidez em um grupo que chega às últimas consequências na guerra, no momento crucial de vida ou morte? Entendo que caracterizá-los como medrosos e tímidos em uma situação do cotidiano faz com que se justifique a conversão dos gentios à cultura europeia, uma vez que na maior parte do tempo são carentes da "salvação". Mas se necessários como força de trabalho, seja na construção ou na guerra, são superestimados pelos franceses, uma vez que a notícia desse desprendimento laboral e guerreiro, ao chegar aos "superiores" em Europa, era mais do que razão para se implementar a construção da França Equinocial, já que haveria braços fortes e amigos para auxiliarem os franceses, e que poderiam facilmente ser conduzidos pelo colonizador. Daí compreender o religioso que a tarefa de converter os selvagens era promissora. No capítulo XVIII de suas crônicas diz:

Os tupinambás, depois de dois anos de convivência com os franceses, aprenderam com estes a tirar o chapéu, a saudar a todos, a beijar as mãos, a cumprimentar (...), a ir à Igreja, benzer-se com água benta (...). Ninguém pois irá contestar-me que não sejam estes fatos bastante para convencer-nos de que devemos esperar e acreditar vir a ser esta nação, com o andar dos tempos, civilizada, educada e honesta (2007, p. 61).

Mas já não o eram honestos e amigos, e por isso civilizados? O relato do religioso francês está eivado de contradições, 
por mais que queira construir seu texto na lógica "nós" e "eles": em momentos clama pela aproximação dos selvagens aos seus hábitos, em outros momentos há a necessidade de tratá-los como o outro a ser civilizado e dominado. E um dos maiores desafios para se chegar à civilidade era o hábito da cauinagem. Este era visto como a barbárie, pois os franceses não entenderam, assim como os demais povos colonizadores, que a beberagem era uma forma de sociabilidade e congraçamento entre os indígenas: "preparam um cauim geral, e como todos partilham dele, se incumbem de cuidar nas plantações, o que fazem com alegria em uma ou duas manhãs, e depois vão beber na casa daquele para quem trabalharam, bebendo cada um quando chega a sua vez" (2007, p. 42). Essa prática ainda hoje é observada, subliminarmente na região da Amazônia oriental, "traduzida" na prática do putirum ou muxirum: o trabalho coletivo e solidário na colheita ou construção, em que a comunidade produz para atender a um dos indivíduos do grupo, realizando-se posteriormente o rodízio em relação aos demais indivíduos necessitados do trabalho coletivo em suas construções e colheitas. A bebedeira é um espaço de sociabilidade e ajuda, mesmo porque a bebida do cauim não deveria ser consumida a qualquer tempo, mas a partir de um momento ritual, em certas ocasiões. Portanto, antes de ser um vício, como atesta o religioso francês - "gostam tanto de vinho a ponto de a embriaguez ser considerada por eles (...) uma grande honra" (2007, p. 70), é uma prática do ethos indígena, por certo herdada nos dias de hoje pelos habitantes da região da Amazônia oriental, como tantos outras que porventura poderão ser estudadas.

\section{Da transculturação à interculturalidade}

Observamos, até aqui, que os contatos culturais oportunizaram práticas transculturadoras mediante narrativas, imagens e objetos. Estar em um Mundus Novus oportunizou ao mesmo tempo a reificação da cultura dominadora e também o questionamento desta, a exemplo de d'Abbeville quando se surpreende com a convivência harmoniosa poligâmica na família indígena, inevitavelmente realizando o comparativismo intercultural. Entendo que momentos como este, na empresa colonizadora, foram para além da simples epifania do estar no mundo dos colonizadores (o que é isso? o que estou fazendo aqui?), sendo a máquina propulsora de um mundo até então inefável. Penso serem estes os momentos de gênese do que somos hoje: ameríndios, latino-americanos, brasileiros, amazônidas? De tudo um pouco ou o nada que é tudo, como o mito em Pessoa: "foi por não ser existindo" (In: poema Mensagem). Da fricção dos contatos culturais surgiram as ficções, em longo processo de transculturação como já sinalizado: desculturação, aculturação e neoculturação.

Creio que hoje esse processo é frequente, isto é, ocorre sempre que são postas culturas em contato, em maior ou menor 
frequência e intensidade, o que me lembra o conceito de poética da diversidade em Édouard Glissant (2005). Observo que desse processo são gerados produtos e práticas que considero interculturais. A historiadora Mary Louise Pratt discrimina os espaços de transculturação como "zonas de contato":

"zonas de contato", espaços sociais onde culturas díspares
se encontram, se chocam, se entrelaçam uma com a outra,
frequentemente em relações extremamente assimétricas de
dominação e subordinação - como o colonialismo, o escrava-
gismo, ou seus sucedâneos ora praticados em todo o mundo
(1999, p. 27).

Todavia, só não concordo com a afirmação da historiadora de que as relações são "extremamente assimétricas". Pode haver sim a assimetria em alguns casos, principalmente quando há o momento inicial de contato cultural, em que se estabelecem os textos da "tradução", como o foi no caso das crônicas aqui estudadas. No entanto, não cabe pensar e falar como se estivéssemos naquele momento genético, pois agora, transcorrido algum tempo, esse momento genético da produção do imaginário transplantado e ressignificado tornou-se uma terceira via de compreensão do que somos, por isso entendo que seja o momento de interculturalidade, de entendermos esses textos como negociação entre culturas, não somente como tensionamentos e recalcamentos: à análise resta desvelar os recalques. Penso ser o conceito de interculturalidade um instrumento prático e praticável para pensarmos nosso momento de desvelamentos, mesmo que não seja um conceito de pleno uso: afinal, vivemos temporalidades em um mesmo espaço e isso concorre para que tenhamos sobreposição de momentos históricos, pois não tenho dúvidas de que vivemos as modernidades e as antiguidades coetaneamente.

Entender a interculturalidade é sine qua non para nossas aventuras de invenção da Amazônia, pois, mediante este concepto, podemos entender que as relações entre culturas postas, em contato, são "las relaciones entre personas de culturas diferentes en la medida que puede sentar las bases, las condiciones y oportunidades para desarrollar prácticas en las cuales el otro es reconocido como un legítimo otro en la convivencia", praticando-se o "reconocimiento y la valoración de aquello que los sujetos tienen, y por lo que pueden ser y son" (VALENZUELA, 2008, p.83).

Por isso, este estudo teve a finalidade de espreitar o momento crucial dos primeiros escritos sobre a Amazônia oriental, como forma de compreensão inicial dos contatos posteriores que foram intensificados. Por certo, os franceses foram frustrados em seu sonho de uma França Equinocial, mas deixaram o registro de um momento em que começaram os contatos culturais na terra brasilis, tão conflituosos, mas tão necessários para que, séculos depois, pudéssemos exercitar a tolerância entre os povos, o que 
até hoje é tão caro, principalmente a quem nos colonizou, sejam franceses ou portugueses. O outro extremo da tolerância é a barbárie, página borrada na história europeia recente, das duas grandes guerras do século XX. Portanto, entender as certidões de batismo da Amazônia oriental, nas crônicas de d'Abbeville e d'Évreux, é entender as relações toleráveis entre os povos.

\begin{abstract}
This article proposes treat of imaginary situations, their narrative representations and imagerys transplanted in the colonization of Brazilian Amazonia during XVII century. Used by religious, French and Portuguese, in their chronicles and sermons in order to translate to the Old World, sights and costumes and appearance of American natives.In particular, we present reports of $\mathrm{Ca}$ puchin priests about Maranhão, by the heavenly imaginary construction of a territory, but had a wild population that needed a messiah to lead to the truth and God. We'll use the work of Claude d'Abbeville and Yves d'Évreux in the exegesis, because they were religious that produced substancial chronicles about the presence of settlers in eastern Amazon on the period. To text analysis we'll use a referential of narratology, discourse analysis and historical studies.
\end{abstract}

Keywords: Imaginary, equinoctial France, Eastern Amazonia, Narratives, Interculturalitys.

\title{
REFERÊNCIAS
}

CUNHA, Euclides da. À margem da história. São Paulo: Martins Fontes, 1999.

D'ABBEVILLE, Claude. História da missão dos padres Capuchinhos na ilha do Maranhão e terras circunvizinhas. Brasília: Senado Federal, 2008.

D'ÉVREUX, Yves. Continuação da história das coisas mais memoráveis acontecidas no Maranhão nos anos de 1613 e 1614. Brasília: Senado Federal, 2007.

ENGELS, Friedrich, MARX, Karl. A ideologia alemã. Rio de Janeiro: Civilização Brasileira, 2007.

FERNANDES, José Guilherme dos Santos. O boi de máscaras: festa, trabalho e memória na cultura popular do Boi Tinga de São Caetano de Odivelas, Pará. Belém: EDUFPA, 2007. 
GIMENEZ, José Carlos. "A presença do imaginário medieval no Brasil colonial: descrições dos viajantes". In: Acta Scientiarium, n.23, v. 1. Maringá, 2001.p. 207-213.

GIRARDET, Raoul. Mitos e mitologias políticas. São Paulo: Companhia das Letras, 1987.

GLISSANT, Édouard. Introdução a uma poética da diversidade. Juiz de Fora: EDUFJF, 2005.

LAPLANTINE, François, TRINDADE, Liana. O que é imaginário. São Paulo: Brasiliense, 1997.

PRATT, Mary Louise. Os olhos do Império: relatos de viagem e transculturação. Bauru, SP: EDUSC, 1999.

RAMA, Ángel. Transculturación narrativa en América Latina. 1.ed. Buenos Aires: Ediciones El Andariego, 2007.

SAMPAIO, Patrícia Melo. Administração colonial e legislação indigenista na Amazônia portuguesa. Os senhores dos rios / organizadores Mary Del Priore, Flavio dos Santos Gomes. Rio de Janeiro: Elsevier, 2003.

VALENZUELA, Estela Maris. Formación docente en contexto de diversidad lingüística y cultural desarrollada en el Centro de Investigación y Formación para la Modalidad Aborigen. Diversidad cultural e interculturalidad en educación superior. Experiencias en América Latina / coordinado por Daniel Mato. Caracas: IESAL-UNESCO, 2008. 